DOI: $10.1515 / \mathrm{amm}-2016-0101$

\author{
E. RUDNIK*,\#, P. SIKORA*
}

\title{
STUDIES ON CEMENTATION OF TIN ON COPPER AND TIN STRIPPING FROM COPPER SUBSTRATE
}

\begin{abstract}
Cementation of tin on copper in acid chloride-thiourea solutions leads to the formation of porous layers with a thickness dependent on the immersion time. The process occurs via $\mathrm{Sn}(\mathrm{II})-\mathrm{Cu}(\mathrm{I})$ mechanism. Chemical stripping of tin was carried out in alkaline and acid solutions in the presence of oxidizing agents. It resulted in the dissolution of metallic tin, but refractory $\mathrm{Cu}_{3} \mathrm{Sn}$ phase remained on the copper surface. Electrochemical tin stripping allows complete tin removal from the copper substrate, but porosity and complex phase composition of the tin coating do not allow monitoring the process in unambiguous way.
\end{abstract}

Keywords: tin; copper; cementation; stripping

\section{Introduction}

Copper and tin belong to the most valuable basic metals for $\operatorname{EU}(5,700 \mathrm{USD} / \mathrm{t} \mathrm{Cu}$ and 14,700 USD/t Sn [1]), which are often obtained from waste materials and scraps. It is estimated, that about $15 \%$ of tin and up to $21 \%$ of copper produced worldwide originate from secondary sources [2]. Tin is used mainly for protective layers on steel packages for food products, as component of solders as well as coatings on copper wires, cables and tubes preventing oxidation of the substrate surface and formation of copper sulfides [3]. Tinned copper wires show beneficial anti-corrosion properties, which make them effective in marine usages as well as in high moisture and humidity environments. Tin coatings $(0.5-5 \mu \mathrm{m})$ can significantly improve the lifespan of copper products, but recycling of tin coated copper scrap and obsolete electric cables is not a simply procedure. Direct casting of tinned copper results in an increase of tin content in the copper melt and its inability to re-use for production of new material with desired properties. To increase the purity of recycled copper, tin stripping from the copper scrap is needed before final copper treatment.

Removal of tin from copper surface is generally performed using hydrometallurgical methods (chemical or electrochemical). Table 1 shows exemplary solutions and conditions proposed for tin stripping. Baths contain oxidation agents and inhibitors of copper dissolution. However, it has to be mentioned that efficiency of tin dissolution depends on the method used previously for tin coating (hot dipping, electroless deposition, electroplating). Electroplated tin layers can be easy stripped completely from the substrate, since no $\mathrm{Cu}_{\mathrm{x}} \mathrm{Sn}_{\mathrm{y}}$ intermetallic compounds are formed between substrate and coat elements. Unfortunately, similar behavior may be not observed, when cementation (immersion process) or dipping of copper in melted tin are used for the tinning.
Therefore, the aim of this work was to investigate the influence of composition of the stripping baths and method (chemical, electrochemical) on the efficiency of removal of tin layers from copper surface produced formerly via immersion deposition.

TABLE 1

Exemplary solutions for tin stripping from copper substrate

\begin{tabular}{|c|c|c|c|}
\hline No & Bath composition & Conditions & Reference \\
\hline \multirow{3}{*}{1} & $25 \mathrm{wt} \% \mathrm{HNO}_{3}$ & & \multirow{3}{*}{ [4] } \\
\hline & $6.5 \mathrm{~g} / \mathrm{L} \mathrm{FeCl}_{3}$ & $20-25{ }^{\circ} \mathrm{C}$ & \\
\hline & $0.03 \mathrm{~g} / \mathrm{L} \mathrm{F} 127 *$ & & \\
\hline \multirow{2}{*}{2} & $20 \%(\mathrm{vol}) \mathrm{CH}_{3} \mathrm{HSO}_{3}(70 \mathrm{wt} \%)$ & $40-45^{\circ} \mathrm{C}$ & \multirow{2}{*}{ [5] } \\
\hline & $80 \mathrm{~g} / \mathrm{L} \mathrm{Fe}\left(\mathrm{NO}_{3}\right) 3.9 \mathrm{H}_{2} \mathrm{O}$ & $3 \mathrm{~min}$ & \\
\hline \multirow{7}{*}{3} & Stage I: & Stage I: & \multirow{7}{*}{ [6] } \\
\hline & $100 \mathrm{~g} / \mathrm{L} \mathrm{C}_{6} \mathrm{H}_{5} \mathrm{NO}_{5} \mathrm{SNa}$ & $40^{\circ} \mathrm{C}$ & \\
\hline & $400 \mathrm{~g} / \mathrm{L} \mathrm{HNO}_{3}$ & $30 \mathrm{~s}$ & \\
\hline & $100 \mathrm{~g} / \mathrm{L} \mathrm{HOCH}_{2} \mathrm{COOH}$ & & \\
\hline & $10 \mathrm{~g} / \mathrm{L} \mathrm{NaCl}$ & Stage II: & \\
\hline & Stage II: & $25^{\circ} \mathrm{C}$ & \\
\hline & $3 \mathrm{~g} / \mathrm{L} \mathrm{FeCl}_{3}$ & $5 \mathrm{~s}$ & \\
\hline \multirow{7}{*}{4} & Stage I: & Stage I: & \multirow{7}{*}{ [7] } \\
\hline & $150 \mathrm{~g} / \mathrm{L} \mathrm{C}_{6} \mathrm{H}_{5} \mathrm{NO}_{5} \mathrm{SNa}$ & $40^{\circ} \mathrm{C}$ & \\
\hline & $200 \mathrm{~g} / \mathrm{L} \mathrm{HBF}_{4}$ & $10 \mathrm{~min}$ & \\
\hline & $50 \mathrm{~g} / \mathrm{L} \mathrm{CH}_{3} \mathrm{COOH}$ & & \\
\hline & Stage II: & Stage II: & \\
\hline & $100 \mathrm{~g} / \mathrm{L} \mathrm{NaClO}_{2}$ & $95^{\circ} \mathrm{C}$ & \\
\hline & $200 \mathrm{~g} / \mathrm{L} \mathrm{NaOH}$ & $6 \mathrm{~min}$ & \\
\hline
\end{tabular}

* AGH UNIVERSITY OF SCIENCE AND TECHNOLOGY, FACULTY OF NON-FERROUS METALS, DEPARTMENT OF PHYSICAL CHEMISTRY AND METALLURGY OF NON-FERROUS METALS, AL. MICKIEWICZA 30; 30-059 CRACOW, POLAND

\# Corresponding author: erudnik@agh.edu.pl 


\begin{tabular}{|c|c|c|c|}
\hline 5 & $\begin{array}{c}100 \mathrm{~g} / \mathrm{L} \mathrm{HNO}_{3}(70 \mathrm{wt} \%) \\
225 \mathrm{~g} / \mathrm{L} \mathrm{H}_{2} \mathrm{SO} 4 \\
80 \mathrm{~g} / \mathrm{L} \mathrm{Fe}\left(\mathrm{NO}_{3}\right)_{3}(45 \mathrm{wt} \%) \\
0.1 \mathrm{~g} / \mathrm{L} \text { inhibitor } \\
\end{array}$ & $\begin{array}{l}30{ }^{\circ} \mathrm{C} \\
2 \min \end{array}$ & {$[8]$} \\
\hline 6 & $\begin{array}{c}6 \%(\mathrm{vol}) \mathrm{H}_{2} \mathrm{SO}_{4} \\
50-100 \mathrm{~g} / \mathrm{L} \mathrm{CuSO}_{4}\end{array}$ & $80^{\circ} \mathrm{C}$ & [9] \\
\hline 7 & $\begin{array}{c}1 \mathrm{~L} \mathrm{HCl}(1,17 \mathrm{~g} / \mathrm{L}) \\
0.125 \mathrm{~L} \mathrm{H}_{2} \mathrm{O} \\
12 \mathrm{~g} \mathrm{Sb}_{2} \mathrm{O}_{3} \\
\end{array}$ & & \multirow{3}{*}[10]{} \\
\hline 8 & $\begin{array}{c}50 \mathrm{~g} / \mathrm{L} \mathrm{Na}_{2} \mathrm{SnO}_{3} \\
90 \mathrm{~g} / \mathrm{L} \mathrm{NaOH}\end{array}$ & $\begin{array}{l}70-90{ }^{\circ} \mathrm{C} \\
1 \mathrm{~A} / \mathrm{dm}^{2}\end{array}$ & \\
\hline 9 & $5 \% \mathrm{NaOH}$ & $1 \mathrm{~A} / \mathrm{dm}^{2}$ & \\
\hline 10 & $\begin{array}{c}0.5 \mathrm{M} \mathrm{C} \mathrm{H} 8 \mathrm{O} 7 \\
0.5 \mathrm{M} \mathrm{C}_{6} \mathrm{H}_{7} \mathrm{O}_{7} \mathrm{Na}\end{array}$ & $\begin{array}{c}\text { Potentiostatic } \\
\text { dissolution }\end{array}$ & [11] \\
\hline
\end{tabular}

* F127 - block copolymer of propylene oxide and ethylene oxide $(\mathrm{M}=12,700 \mathrm{u}, 70 \%$ ethylene oxide)

\section{Experimental}

Deposition of tin on copper substrate was performed using cementation method. Before coating, copper plates (2 $\mathrm{cm} \times 2 \mathrm{~cm}$ ) were grinded with sand papers, washed in water and acetone, then polished in a mixture of concentrated acids $\left(\mathrm{HNO}_{3}: \mathrm{H}_{3} \mathrm{PO}_{4}: \mathrm{CH}_{3} \mathrm{COOH}\right.$ 1:3:1), washed in water and ethanol, then dried.

Copper plates were tinned in a solution containing: $0.1 \mathrm{M}$ $\mathrm{SnCl}_{2}, 0.4 \mathrm{M} \mathrm{SC}\left(\mathrm{NH}_{2}\right)_{2}$ and $0.4 \mathrm{M} \mathrm{HCl}$. Deposition was carried out at the temperature of $80^{\circ} \mathrm{C}$ for 2-45 min. All samples were weighted before and after cementation.

Chemical tin stripping was performed using solutions of various compositions. These were: $2 \mathrm{M} \mathrm{NaOH} ; 2 \mathrm{M} \mathrm{NaOH}$ with addition of $\mathrm{H}_{2} \mathrm{O}_{2}(1-6 \%)$ or $\left(\mathrm{NH}_{4}\right)_{2} \mathrm{~S}_{2} \mathrm{O}_{8}(3 \%) ; 3 \mathrm{M} \mathrm{H}_{2} \mathrm{SO}_{4}$ with $5.5 \% \mathrm{CuSO}_{4}$. Stripping was carried out usually at the temperature of $80{ }^{\circ} \mathrm{C}$ for $1-20 \mathrm{~min}$. Before and after process samples were weighted.

Electrochemical tin stripping was performed galvanostatically using $0.1 \mathrm{M} \mathrm{NH} \mathrm{NH}_{4} \mathrm{Cl}+0.1 \mathrm{M} \mathrm{CH}_{3} \mathrm{COOH}$ solution. Anodic current density was $10 \mathrm{~mA} / \mathrm{cm}^{2}$. Potential of the anode was registered versus saturated calomel electrode (SCE). Counter electrode was platinum plate. Electrolysis was carried out at room temperature.

Surface and cross-sections of the samples after tin deposition and tin stripping were observed using optical microscope (NIKON), while phase composition of the samples was determined using X-ray diffractometry (Rigaku).

\section{Results and discussion}

\subsection{Cementation of tin}

Electroless deposition is one of the simplest methods of formation of thin metallic layers on various substrates. Compared to other techniques (e.g. CVD, PVD, electrodeposition) process does not require cost and sophisticated equipment or special conditions. There are two hydrometallurgical electroless methods used for deposition of tin films: cementation (immersion process) [12-14] and autocatalytic deposition [15].

Cementation occurs via displacement of nobler metal ions from aqueous solution by the less noble metal. Cementation of tin on copper is typically carried out using acidic solutions of $\mathrm{Sn}$ (II) salts in the presence of thiourea $\mathrm{SC}\left(\mathrm{NH}_{2}\right)_{2}[12,13]$. Two mechanisms of the process are proposed in the literature:

a) reduction of $\mathrm{Sn}(\mathrm{II})$ ions with formation of $\mathrm{Cu}(\mathrm{I})$ ions [12]:

$$
2 \mathrm{Cu}+\mathrm{Sn}^{2+} \rightarrow \mathrm{Sn}+2 \mathrm{Cu}^{+}
$$

b) reduction of ions $\mathrm{Sn}$ (II) ions with formation of $\mathrm{Cu}(\mathrm{II})$ ions [13]:

$$
\mathrm{Cu}+\mathrm{Sn}^{2+} \rightarrow \mathrm{Sn}+\mathrm{Cu}^{2+}
$$

Despite that copper is more noble metal than tin, the presence of thiourea changes conditions for tin cementation. Large stability constants of copper-thiourea complexes (Table 2):

$$
\mathrm{Cu}^{+}+4 \mathrm{SC}\left(\mathrm{NH}_{2}\right)_{2} \rightarrow\left[\mathrm{Cu}\left(\mathrm{SC}\left(\mathrm{NH}_{2}\right)_{2}\right)_{4}\right]^{+}
$$

$$
\mathrm{Cu}^{2+}+4 \mathrm{SC}\left(\mathrm{NH}_{2}\right)_{2} \rightarrow\left[\mathrm{Cu}\left(\mathrm{SC}\left(\mathrm{NH}_{2}\right)_{2}\right)_{4}\right]^{2+}
$$

shift the electrode potentials of $\mathrm{Cu} / \mathrm{Cu}(\mathrm{I})$ and $\mathrm{Cu} / \mathrm{Cu}$ (II) systems to more electronegative values than the potential of the $\mathrm{Sn} / \mathrm{Sn}$ (II) electrode [12]. This results in the spontaneous dissolution of copper with simultaneous tin deposition.

TABLE 2

Stability constants of copper ion-thiourea complexes (log values) at $25{ }^{\circ} \mathrm{C}[16]$

\begin{tabular}{|c|c|c|c|}
\hline \hline Copper ion & $\boldsymbol{\beta}_{2}$ & $\boldsymbol{\beta}_{3}$ & $\boldsymbol{\beta}_{4}$ \\
\hline \multirow{2}{*}{$\mathbf{C u}(\mathbf{I})$} & 13.04 & 15.88 & 18.66 \\
& 12.30 & 14.30 & 15.53 \\
\hline \multirow{2}{*}{$\mathbf{C u}(\mathbf{I I})$} & 11.28 & 13.73 & 15.70 \\
& 13.0 & 15.9 & 18.1 \\
\hline
\end{tabular}

Cementation of tin on copper can also occur in strongly alkaline solutions [14], where Sn(II) ions exist as hydroxycomplexes:

$$
\mathrm{Cu}+\mathrm{Sn}(\mathrm{OH})_{3}{ }^{-} \rightarrow \mathrm{Sn}+\mathrm{Cu}(\mathrm{OH})_{3}{ }^{-}
$$

Regardless on $\mathrm{pH}$ of solutions used, tin plating can be hindered by the occurrence of side reactions. The most important are: oxidation of $\mathrm{Sn}$ (II) to Sn(IV) and hydrolysis of tin salts as well as secondary dissolution of metallic tin under action of acid solution [12]:

$$
\mathrm{Sn}+2 \mathrm{H}^{+} \rightarrow \mathrm{Sn}^{2+}+\mathrm{H}_{2}
$$

In the present study deposition of tin was carried out in acid chloride-thiourea solution. Fig.1 shows exemplary crosssections of tinned copper samples. Obtained coatings were rather porous, but gray layer of metallic tin was clearly visible on the red copper surface. Microscopic observations enabled 
to determine thickness of the coatings. Obtained average values are summarized in Table 3. It was found that increased deposition time from $2 \mathrm{~min}$ to $45 \mathrm{~min}$ favored formation of tin layers with the thickness from the range of 1-21 $\mu \mathrm{m}$. Obtained values are higher than the data showed in the literature for the same temperature and similar plating times, where deposits of the thickness 1.2-1.6 $\mu \mathrm{m}$ (15 $\mathrm{min})$ were reported. However, it has to be noted that the growth of the coatings is hindered by the reduction of metallic copper area due to covering the substrate by metallic tin.
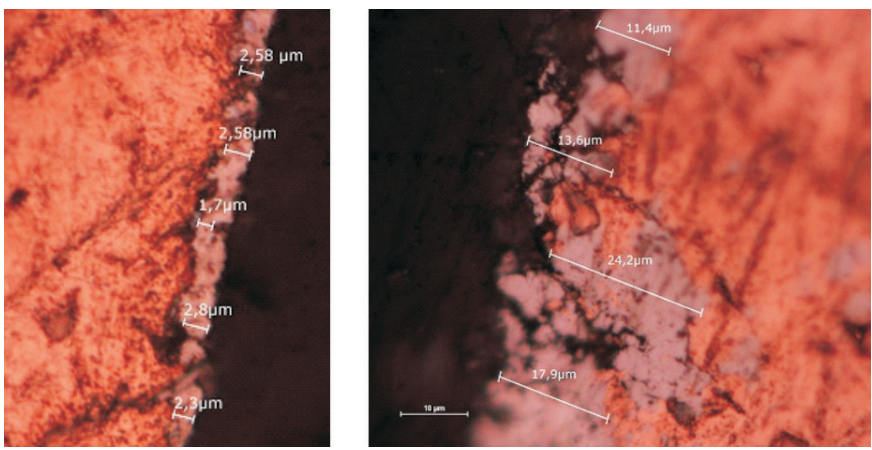

Fig.1. Cross-sections of tin coated copper samples. Deposition time: $5 \mathrm{~min}$ (left) and $15 \mathrm{~min}$ (right)

Thickness of tin layers

TABLE 3

\begin{tabular}{|c|c|c|}
\hline \hline \multirow{2}{*}{$\begin{array}{c}\text { Deposition } \\
\text { time, } \\
\text { min }\end{array}$} & \multicolumn{2}{|c|}{ Average thickness of coatings, $\boldsymbol{\mu m}$} \\
\cline { 2 - 3 } & $\begin{array}{c}\text { microscopic } \\
\text { observations }\end{array}$ & $\begin{array}{c}\text { mass change acc.to } \\
\text { eq.(1) }\end{array}$ \\
\hline $\mathbf{2}$ & $1.4 \pm 0.1$ & 1.2 \\
$\mathbf{5}$ & $2.4 \pm 0.2$ & 2.3 \\
$\mathbf{1 5}$ & $11.2 \pm 1.1$ & 10.8 \\
$\mathbf{3 0}$ & $14.8 \pm 1.4$ & 15.6 \\
$\mathbf{4 5}$ & $21.0 \pm 2.1$ & 20.1 \\
\hline
\end{tabular}

Gravimetric analysis showed decrement of the mass of the samples $\Delta m$ after completed tin plating. Theoretical calculations of thicknesses of the coatings according to the equations (1) and (2) showed very good conformity of the results only for tin deposition according to $\mathrm{Sn}(\mathrm{II})-\mathrm{Cu}(\mathrm{I})$ mechanism (Table 3 ). In the latter case thickness of the deposits $l_{\mathrm{Sn}}$ was calculated according to the following formula:

$$
l_{S n}=\frac{\Delta m \cdot M_{S n}}{\left(M_{S n}-2 M_{C u}\right) \cdot S \cdot d_{S n}}
$$

where: $M_{S n}$ and $d_{S n}$ - molar mass and density of tin, respectively; $M_{C u}$ - molar mass of copper; $S$ - surface area of the sample.

Phase analysis of the tin coated substrates confirmed the presence of both metals in their pure forms (copper - cubic, tin - tetragonal), but additional $\mathrm{Cu}_{\mathrm{x}} \mathrm{Sn}_{\mathrm{y}}$ intermetallic compounds were not detected (Fig.2).

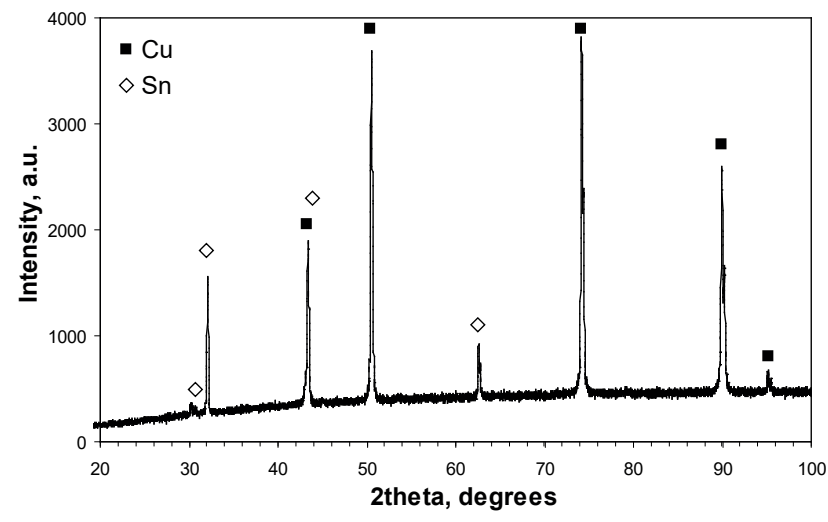

Fig. 2. Diffraction pattern of tin coated copper substrate

\subsection{Stripping of tin}

Metallic tin was stripped from the copper substrate in alkaline and acid solutions due to amphoteric properties of tin. Fig. 3 shows exemplary results obtained for the samples coated with tin of a thickness of $4.5 \pm 0.2 \mu \mathrm{m}$. The lowest stripping efficiency was observed in $\mathrm{NaOH}$ solution with no additives, while the most aggressive action of the bath was found in the $\mathrm{H}_{2} \mathrm{SO}_{4}-\mathrm{CuSO}_{4}$ system. Ammonium persulfate proved to be high oxidation agent, since copper substrate was covered with thick black layer of copper(II) oxide, although tin(II) oxide was also detected (Fig.4b). Alkaline solution with hydrogen peroxide was the middle active solution for tin stripping, but tin was not dissolved completely and tin layer with a thickness of about $0.8 \mu \mathrm{m}$ remained on the substrate. It was also identified that refractory soluble phase $\mathrm{Cu}_{3} \mathrm{Sn}$ was formed during the cementation stage, since it was found in all samples after stripping treatment (Fig.5).

Fig. 6 shows the influence of $\mathrm{H}_{2} \mathrm{O}_{2}$ concentration on the mass decrement of tin. It was observed that increased concentration of oxidizing agent was unfavorable for tin dissolution due to passivation of tin surface with $\mathrm{SnO}$ (Fig.4a).

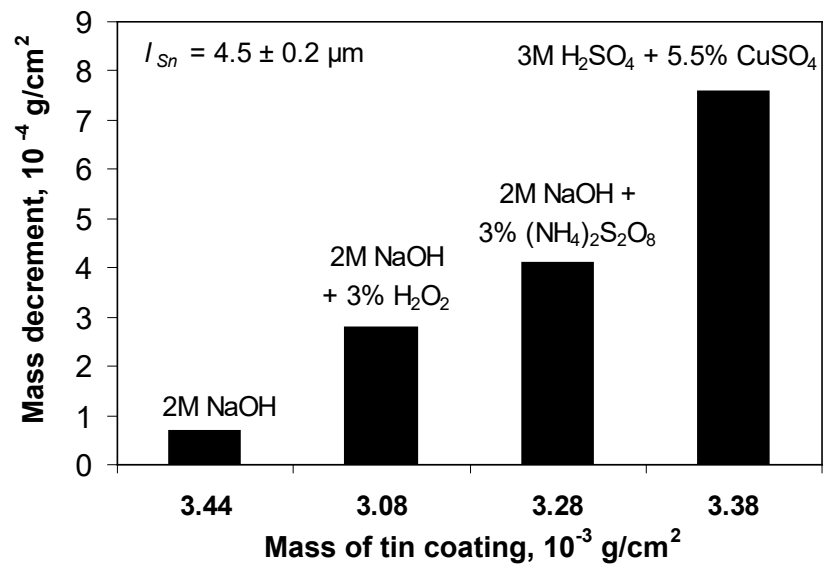

Fig. 3. Mass decrement of the samples during tin stripping for $20 \mathrm{~min}$ in various solutions $\left(80^{\circ} \mathrm{C}\right)$ 

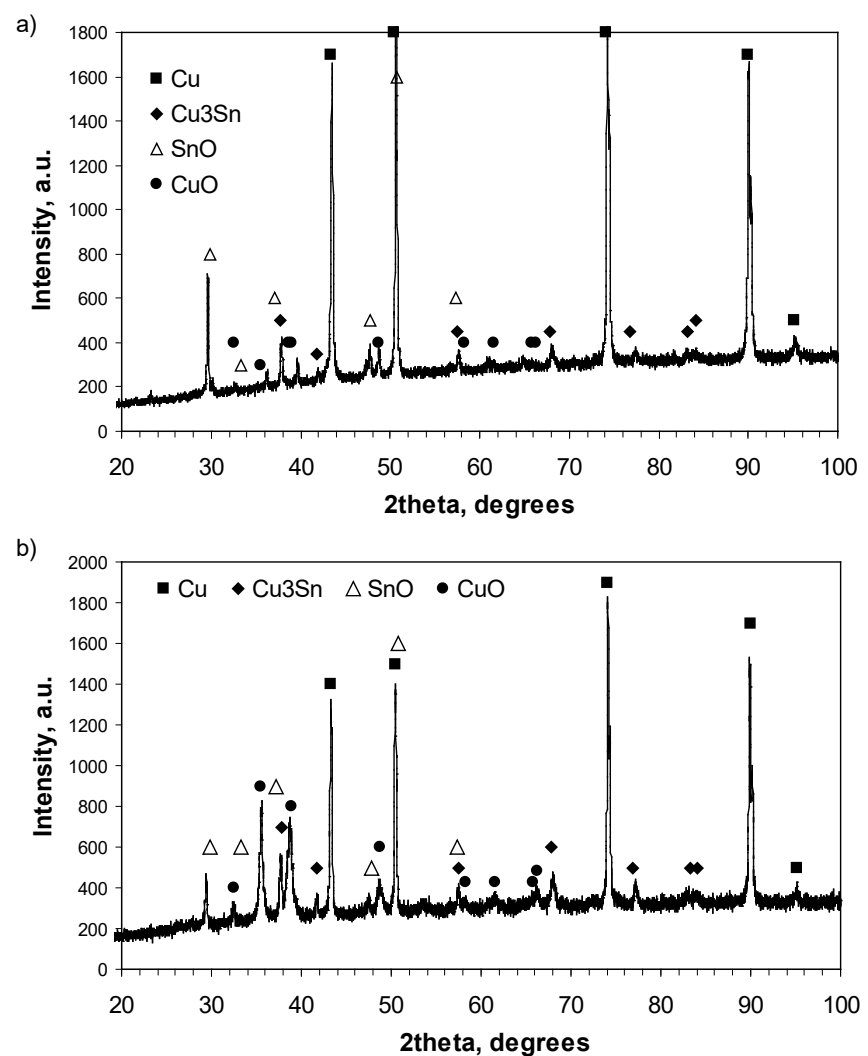

Fig.4. Diffraction pattern of tin stripped copper substrate in solutions: a) $2 \mathrm{M} \mathrm{NaOH}+3 \% \mathrm{H}_{2} \mathrm{O}_{2}$, b) $2 \mathrm{M} \mathrm{NaOH}+3 \%\left(\mathrm{NH}_{4}\right)_{2} \mathrm{~S}_{2} \mathrm{O}_{8}$
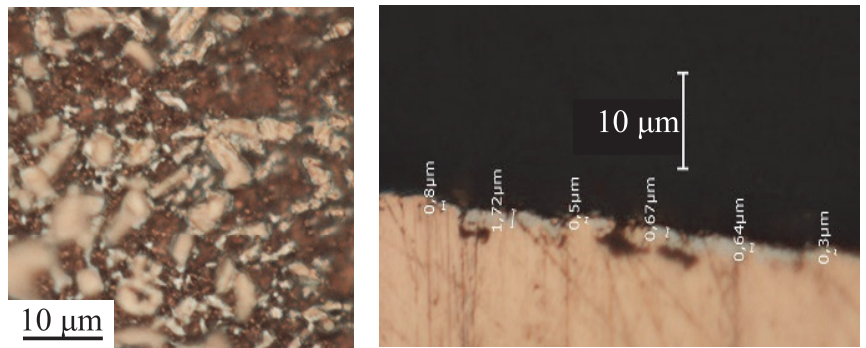

Fig.5. Surface and cross-section of the samples after tin stripping in $2 \mathrm{M} \mathrm{NaOH}+3 \% \mathrm{H}_{2} \mathrm{O}_{2}$ solution for $20 \min \left(80{ }^{\circ} \mathrm{C}\right)$

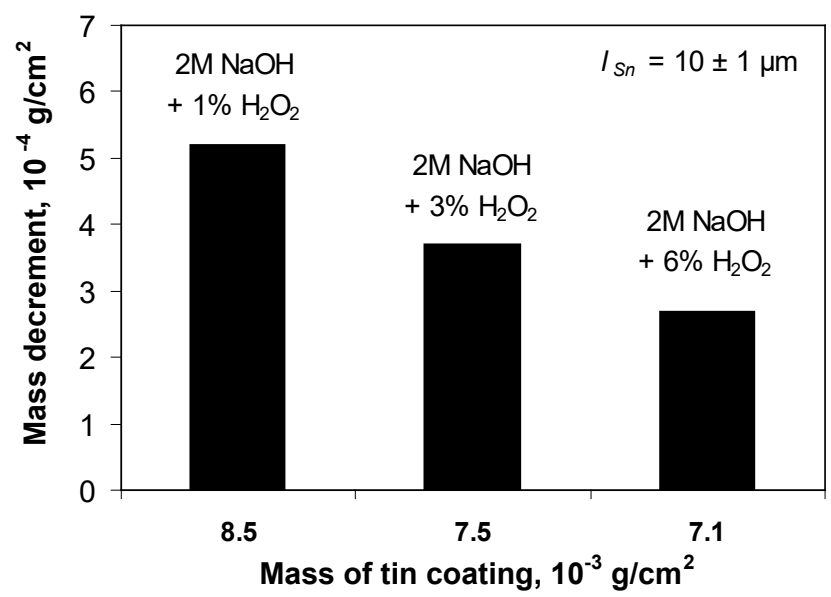

Fig.6. The influence of $\mathrm{H}_{2} \mathrm{O}_{2}$ concentration on tin mass decrement during stripping in $\mathrm{NaOH}$ solutions for $20 \mathrm{~min}\left(80^{\circ} \mathrm{C}\right)$
Obtained results show that chemical dissolution of metallic tin cemented on the copper surface requires addition of oxidizing agent, but it is not enough for dissolution of refractory $\mathrm{Cu}_{3} \mathrm{Sn}$ phase formed during plating. Moreover, the process is hindered by formation of passive films on the samples surface. Increased temperature $\left(90^{\circ} \mathrm{C}\right)$ or prolongated time of the stripping does not improve efficiency of the chemical dissolution (results not presented). Therefore electrochemical method was also tested.

Anodic dissolution of metallic coatings is used for determination of thickness of the layers by means of coulometric method [17]. In the present paper similar methodology was applied for removal if tin layer. It was observed that dissolution of tin starts at the anode potential of about $100 \mathrm{mV}$ (VS. SCE), but then potential gradually increases due to anodic oxidation of metal, intermetallic phase and subsequently the copper substrate. Final anodic potential was maintained at about 800$1200 \mathrm{mV}$ (SCE). However, porous structure of the coatings and their complex composition disturb changes of the potential, hence it could not be used for monitoring the progress the tin dissolution. Despite of that phase analysis of the samples after anodic oxidation did not show the presence of tin or tin-copper compounds (Fig.7). Only copper and copper(I) oxide as final products of the electrolysis were identified.

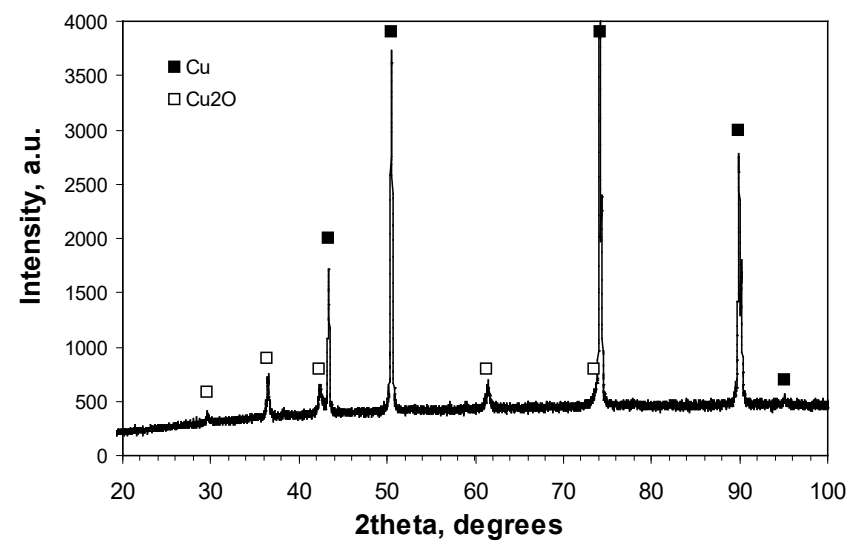

Fig.7. Diffraction pattern of electrochemically tin stripped copper substrate

\section{Conclusions}

Cementation of tin on copper in acid chloride-thiourea solutions allowed to obtain porous layers with a thickness from the range of 1-21 $\mu \mathrm{m}$, depending in the immersion time. Studies confirmed that the process occurs via $\mathrm{Sn}(\mathrm{II})-\mathrm{Cu}(\mathrm{I})$ mechanism.

Chemical stripping of tin carried out in various solutions (alkaline and acid in the presence of oxidizing agent) resulted in the dissolution of metallic tin, but refractory $\mathrm{Cu}_{3} \mathrm{Sn}$ phase remained on the copper surface. Oxidation agents enabled dissolution of the metals, but too high concentration of the additives resulted in the passivation of tin and copper.

Electrochemical dissolution of tin resulted in complete tin removal from the copper substrate, but porosity and complex phase composition of the coatings do not allow monitoring the process in unambiguous way. It seems that the anodic 
oxidation can be finished when the sample potential reaches values above $600 \mathrm{mV}$ (SCE).

\section{REFERENCES}

[1] www.lme.com (16.07.2015).

[2] T.Smakowski, R.Ney, K.Galos (red.): Bilans gospodarki surowcami mineralnymi Polski i świata. 2012. Państwowy Instytut Geologiczny - Państwowy Instytut Badawczy, Warszawa (2014).

[3] L. Shreir, Korozja, PWN, Warszawa (1966).

[4] US Patent 4949752

[5] US Patent 4957653

[6] US Patent 5035749
[7] US Patent 4687545

[8] US Patent 5234542

[9] US Patent 2721119 A

[10] Poradnik galwanotechnika, PWN, Warszawa (2000).

[11] US Patent 4264419

[12] J.Bieliński, A.Araźna, A.Rzepka, Inż. Powierz. 4, 34 (2006).

[13] E.Huttunen-Saarivirta, Surf. Coat.Technol. 160, 288 (2002).

[14] A.Molenaar, J.J.C.Coumans: Surf. Technol. 6, 265 (1982).

[15] A.Molenaar, J.W.G.de Bakker: J. Electrochem. Soc. 136(2), 378 (1989).

[16] The IUPAC stability constants database, Academic Software and IUPAC (1992-2000).

[17] T.Biestek, S.Sękowski, Metody badania powłok metalowych, PWN, Warszawa (1973). 
